\title{
DAMPAK PEMBANGUNAN JALAN TOL SOLO-KERTOSONO TERHADAP HAK EKONOMI MASYARAKAT DESA KASREMAN KECAMATAN GENENG KABUPATEN NGAWI
}

\author{
Uswatun Khasanah $^{1}$, Nurhadji Nugraha ${ }^{2}$, Wawan Kokotiasa ${ }^{3}$ \\ Universitas PGRI Madiun $^{1}$, Universitas PGRI Madiun ${ }^{2}$, Universitas PGRI Madiun ${ }^{3}$ \\ Email : uswatunk002@yahoo.com,wawankokotiasa@unipma.ac.id ${ }^{2}$, \\ nurhadjinugraha@unipma.ac.id ${ }^{3}$
}

Naskah diterima: 08/09/2017 revisi: 24/10/2017 disetujui: 24/10/2017

\begin{abstract}
Abstrak
Tujuan penelitian ini adalah untuk mengetahui dampak pembangunan jalan tol SoloKertosono terhadap hak ekonomi masyarakat Desa Kasreman Kecamatan Geneng Kabupaten Ngawi. Jenis penelitian ini adalah deskriptif dengan menggunakan pendekatan kualitatif. Penelitian dilakukan di Desa Kasreman Kecamatan Geneng Kabupaten Ngawi dengan teknik pengumpulan data melalui wawancara, observasi dan dokumentasi. Kesimpulan dari hasil penelitian menunjukkan bahwa pembangunan jalan tol Solo-Kertosono mengakibatkan dampak positif dan negatif. Dampak positif yaitu membuka peluang bagi pelaku usaha untuk membuka usaha sekitar pembangunan jalan tol, sedangkan dampak negatifnya pembangunan jalan tol menyebabkan pendapatan petani menurun karena lahan pertanian berkurang, tidak dapat mengurangi jumlah pengangguran di Desa Kasreman karena tidak adanya pelibatan masyarakat dalam pembangunan tersebut.Pembangunan jalan tol Solo-Kertosono merupakan pembangunan yang tidak berwawasan lingkungan karena pembangunan tersebut mengakibatkan berkurangnya lahan yang masih produktif sekitar $12 \mathrm{Ha}$, menyebabkan hilangnya saluran irigasi sawah, hilangnya akses jalan menuju sawah seberang serta meningkatnya polusi udara karena banyaknya kendaraan besar bermuatan material.
\end{abstract}

Kata kunci: Pembangunan Jalan Tol, Hak Ekonomi

\section{THE IMPACT OF SOLO-KERTOSONO TOLL ROAD CONSTRUCTION ON THE ECONOMIC RIGHTS OF THE VILLAGE COMMUNITY OF KASREMAN GENENG NGAWI DISTRICT}

\begin{abstract}
The purpose of this study is to determine the impact of the construction of SoloKertosono toll road to the economic rights of the people of Kasreman Village, Geneng, Ngawi District. The type of this research is descriptive by using qualitative approach. The research was conducted in Kasreman Village, Geneng Subdistrict of Ngawi District with data collecting technique through interview, observation and documentation. The conclusion of the research shows that the construction of the Solo-Kertosono toll road has a positive and negative impact. Positive impact is opening opportunities for business actors to open a business around toll road development, while the negative impact of toll road development causes farmers' income decreased due to reduced agricultural land, can not reduce the number of unemployed in Kasreman village due to the absence of public involvement in the development. the Solo-Kertosono toll road is an environmentally insecure development because the development resulted in less productive land loss of around $12 \mathrm{Ha}$, causing loss of irrigation channels, loss of access road to the other rice fields and increased air pollution due to the large number of large vehicles loaded with material.
\end{abstract}

Keywords: Toll Road Construction, Economic Rights

Copyright (C) 2017, Citizenship Jurnal Pancasila dan Kewarganegaraan

Avaliable online at : http://e-journal.unipma.ac.id/index.php/citizenship

ISSN: $2302-433 \mathrm{X}$ (print) 2579-5740 (online) 


\section{PENDAHULUAN}

Pembangunan perlu dilakukan untuk mencapai kualitas kehidupan yang lebih baik. Disamping itu, adanya tujuan nasional Indonesia yang tersirat dalam Pembukaan Undang-Undang Dasar Republik Indonesia Tahun 1945 alenia 4 merupakan bukti bahwa ada tujuan yang hendak dicapai oleh bangsa Indonesia melalui pembangunan nasional. Tujuan nasional bangsa Indonesia yang tersirat dalam Pembukaan UndangUndang Dasar Republik Indoesia Tahun 1945 alenia 4 yaitu sebagai berikut: "Melindungi segenap bangsa dan seluruh tumpah darah Indonesia memajukan kesejahteraan umum, mencerdaskan kehidupan bangsa dan ikut melaksanakan ketertiban dunia yang berdasarkan kemerdekaan, perdamaian abadi dan keadilan sosial". Untuk dapat melaksanakan tujuan nasional tersebut pemerintah bersama rakyat harus mampu bekerja sama dalam mewujudkannya melalui pembangunan nasional yang dilaksanakan secara berkesinambungan.

Menurut Oos Anwas (2014: 42) menjelaskan Pembangunan ada 2 (dua) macam yaitu pembangunan sarana fisik seperti membangun gedung, jembatan, jalan, pelabuhan atau pembangunan lainnya yang relatif mudah dan kongkrit. Artinya pembangunan sarana fisik mudah dilihat dan dirasakan manfaatnya. Sedangkan pembangunan non fisik seperti pembangunan rehabilitasi mental, pendidikan atau pelatihan yang tidak tampak dan tidak mudah dirasakan hasilnya. Namun pembangunan ini sifatnya investasi jangka panjang, hasilnya bisa nampak setelah beberapa waktu ke depan.

Pembangunan tidak hanya dilakukan pada aspek pemberdayaan masyarakat yang meliputi bidang pendidikan, sosial, ekonomi, politik, dan budaya akan tetapi juga pada aspek insfrastrukturnya seperti pembangunan jalan, jembatan, pasar, dan sarana prasarana publik lainnya. Pembangunan pada aspek insfrastruktur yang lebih memerlukan ruang atau tanah luas harus tetap mempertimbangkan ekosistem lingkungan. Pembangunan perlu dilakukan akan tetapi pembangunan haruslah tidak merusak lingkungan baik itu lingkungan biotik (makhluk hidup) maupun abiotik (tak hidup). Hal tersebut dikarenakan manusia adalah bagian dari lingkungan sehingga manusia akan terpengaruh oleh adanya pembangunan. Untuk itu perlu adanya konsep pembangunan jangka panjang yang berwawasan lingkungan, maksudnya adalah pembangunan yang memperhatikan kelestarian lingkungan dan ekologi manusia. Menurut Rahardjo, (2013: 35) menjelaskan tujuan pembangunan pada hakikatnya adalah menciptakan kemajuan sosial ekonomi secara berkesinambungan, dengan tidak mengabaikan persamaan hak dan menjunjung tinggi prinsip-prinsip keadilan bagi masyarakat secara keseluruhan. Dari pernyataan tersebut dapat dipahami pembangunan dilaksanakan secara seimbang dengan tidak mengabaikan hak masyarakat lainnya.

Salah satu pembangunan insfrastruktur yang memerlukan lahan atau tanah sangat luas adalah pembangunan jalan tol. Sebab jalan tol didesain khusus sebagai jalan alternatif jalur darat yang bebas dari hambatan. Peraturan Pemerintah Nomor 15 tahun 2005 Tentang Jalan Tol pada Pasal 1 ayat (2) menjelaskan bahwa jalan tol adalah jalanan umum yang merupakan bagian sistem jaringan jalan dan sebagai jalan nasional yang penggunaannya diwajibkan membayar tol

Dengan adanya pembangunan jalan tol ini bertujuan untuk meningkatkan aksesibilitas dan kapasitas jaringan jalan dalam melayani lalu lintas. Pembangunan jalan tol tidak lepas dari aspek fisik dan aspek non fisik pada masyarakat. Aspek fisik berkaitan dengan lingkungan sedangkan aspek non fisik adalah masalah sosial masyarakat. Kedua aspek tersebut tentunya dirasakan secara langsung oleh masyarakat yang terkena dampak dari adanya pembangunan jalan tol tersebut. Pembangunan jalan tol yang 
menghubungkan 2 (dua) propinsi yaitu Propinsi Jawa Tengah dan Jawa Timur ini merupakan proyek transjawa yang disebut sebagai mega proyek. Proyek jalan tol ini adalah jalan tol Solo-Kertosono yang dibagi ke dalam 2 (dua) ruas yaitu Solo-Ngawi dan Ngawi-Kertosono. Wilayah Kabupaten Ngawi merupakan salah satu dari 6 (enam) kabupaten yang dilewati oleh pembangunan jalan tol sehingga sebagian masyarakat Kabupaten Ngawi tidak lepas dari dampak sosial dan ekonomi akibat pembangunan tersebut.

Jalan tol memiliki beberapa tahap pembangunan. Untuk tahap pelaksanaan yang pertama adalah prakonstruksi yaitu pembebasan lahan untuk proyek jalan tol. Pembebasan lahan pada proyek jalan tol Solo-Kertosono ini melewati lahan yang sebagian besar digunakan penduduk desa untuk pertanian. Untuk itu, masyarakat yang terkena pembebasan lahan untuk pembangunan jalan tol mendapatkan kompensasi sebagai ganti rugi berupa uang tunai sebesar lahan yang dilewati proyek jalan tol tersebut. Meskipun demikian dampak dari pembebasan lahan untuk pembangunan jalan tol sangat dirasakan oleh masyarakat desa terutama petani sebab lahan pertanian yang dijadikan sumber mata pencaharian utama semakin berkurang. Selain itu, lahan pertanian menjadi 2 (dua) bagian karena terpisah oleh pembangunan jalan tol, hal tersebut tentunya menjadi kendala petani mengenai irigasi atau pengairan. Dampaknya adalah pada hak ekonomi masyarakat berkaitan dengan haknya sebagai warga negara untuk mendapatkan kemakmuran dari negara sebagai berikut jumlah pendapatan dari pertanian menurun sebab lahan yang digunakan untuk kegiatan pertanian semakin berkurang hal tersebut berkaitan dengan hak masyarakat untuk mendapatkan pekerjaan dan penghidupan yang layak serta ketidakpuasan masyarakat atas nilai dan proses ganti rugi (lahan, pekarangan dan bangunan). Sedangkan Heri dan Jumanta
(2010: 65) menjelaskan bahwa hak asasi ekonomi (proverty rights), yaitu hak untuk memiliki sesuatu, membeli, dan menjual sesuatu serta memanfaatkannya.

Padahal dalam Undang-Undang Dasar Negara Republik Indonesia Tahun 1945 Pasal 33 ayat (3) yang menjelaskan bahwa bumi, air dan kekayaan alam yang terkandung di dalamnya yang diletakkan dalam penguasaan negara itu digunakan untuk mewujudkan sebesar-besarnya kemakmuran seluruh rakyat Indonesia.

Fokus penelitian dimaksudkan untuk memperjelas beberapa masalah dalam suatu penelitian. Berdasarkan latar belakang masalah, maka fokus penelitian dalam penelitian ini adalah dampak pembangunan jalan tol Solo-Kertosono terhadap hak ekonomi, pembangunan jalan tol yang berwawasan lingkungan, mekanisme ganti rugi yang sesuai prosedur, pelibatan atau partisipasi masyarakat Desa Kasreman dalam pembangunan jalan tol soloKertosono.

Berdasarkan latar belakang dan fokus penelitian tersebut, maka tujuan penelitan ini adalah untuk mengetahui bagaimana dampak positif dan negatif Pembangunan Jalan Tol Solo-Kertosono terhadap hak ekonomi masyarakat Desa Kasreman Kecamatan Geneng Kabupaten Ngawi, untuk mengetahui solusi yang dapat ditawarkan dalam pembangunan jalan tol Solo-Kertosono untuk melindungi hak ekonomi masyarakat Desa Kasreman Kecamatan Geneng Kabupaten Ngawi.

Kegunaan penelitian secara umum, hasil penelitian ini diharapkan dapat dijadikan titik tolak untuk penelitian sejenis yang lebih mendalam dan dalam lingkup yang lebih luas.Selain itu penelitian ini juga bermanfaat untuk dijadikan referensi bagi peneliti selanjutnya yang terkait dengan pembangunan jalan tol Solo-Kertosono. Dan secara praktis, untuk masyarakat Desa Kasreman, hasil penelitian ini dapat dijadikan suatu saran pemikiran kepada pemerintahan desa dalam melindungi hak 
ekonomi masyarakat terkait adanya pembangunan jalan tol atau pembangunan sejenis.

\section{METODE}

\section{Jenis Penelitian}

Penelitian ini menggunakan pendekatan deskriptif-kualitatif. Menurut Satori dan Komariah, (2012: 22) menjelaskan bahwa Penelitian kualitatif adalah penelitian yang menekankan pada quality atau hal yang terpenting dari sifat suatu barang/jasa. Hal terpenting dari suatu barang atau jasa berupa kejadian/fenomena/gejala sosial adalah makna dibalik kejadian tersebut yang dapat dijadikan pelajaran berharga bagi suatu pengembangan konsep teori. Sedangkan jenis penelitian ini adalah adalah deskriptif. Deskriptif merupakan data yang dikumpulkan adalah berupa kata-kata, gambar, dan bukan angka-angka. Dengan demikian, laporan penelitian akan berisi kutipan-kutipan data untuk memberikan gambaran penyajiann laporan tersebut.

\section{Waktu dan Tempat Penelitian}

Penelitian ini dilaksanakan di Desa Kasreman Kecamatan Geneng Kabupaten Ngawi. Waktu yang diperlukan dalam penelitian ini yaitu selama 6 bulan dari bulan Februari 2017 sampai dengan bulan Juli 2017.

\section{Target/Subjek Penelitian}

Adapun narasumber yang dijadikan sebagai informan adalah Masyarakat Desa Kasreman Kecamatan Geneng Kabupaten Ngawi, dengan klasifikasi yaitu kepala desa, yang mempunyai tugas sebagai kepala pemerintahan desa yang mengetahui keseluruhan pembangunan jalan tol yang melewati Desa Kasreman Kecamatan Geneng Kabupaten Ngawi dan pelaku ekonomi, yang terdiri dari pedagang, petani dan masyarakat Desa Kasreman yang terkena dampak langsung pembebasan lahan serta masyarakat yang tidak terkena dampak secara langsung dalam pembangunan jalan tol Solo-Kertosono.

\section{Prosedur}

Prosedur penelitian ini dilakukan meliputi 4 (empat) tahap yaitu:

\section{Tahap pra lapangan}

Pada tahap ini peneliti membuat rancangan penelitan, membuat instrumen penelitian dan membuat surat ijin penelitian. Menyusun proposal penelitian, ini digunakan untuk meminta izin kepada desa yang terkait sesuai dengan sumber data yang diperlukan.

\section{Tahap pekerjaan lapangan}

Mengumpulkan data mengenai dampak pembangunan jalan tol Solo-Kertosono terhadap hak ekonomi masyarakat Desa Kasreman. Data tersebut dapat diperoleh dengan: Observasi langsung dan pengambilan data dari lapangan; Wawancara dengan masyarakat yang terkena dampak langsung dari adanya pembangunan jalan tol Solo-Kertosono; Wawancara dengan Kepala Desa Kasreman; Dokumentasi.

\section{Tahap analisis data}

Meliputi analisis data baik yang diperoleh dari observasi, wawancara, dokumentasi. Kemudian dilakukan penafsiran data sesuai dengan konteks permasalahan yang diteliti selanjutnya melakukan pengecekan keabsahan data dengan cara mengecek sumber data yang didapat.

\section{Tahap penulisan laporan}

Pada tahap ini peneliti menyusun data dan kemudian menyajikan data dalam bentuk penelitian.

\section{Data, Intrumen, dan Teknik Pengumpulan Data}

Jenis data merupakan data yang didapat dari informan. Jenis data ada 2 jenis yaitu data primer dan data sekunder. Menurut Subagyo (2015: 87) menjelaskan "data primer adalah data yang diperoleh secara langsung dari masyarakat baik yang dilakukan melalui wawancara, observasi dan 
alat lainnya. Data primer diperoleh secara mentah-mentah dari masyarakat dan masih memerlukan analisa lebih lanjut". Jadi data yang didapat berasal dari informan yang memiliki jabatan/status yang ada di desa Kasreman yaitu Kepala Desa Kasreman, Pamong Desa Kasreman, masyarakat Desa Kasreman yang terkena pembebasan lahan untuk pembangunan jalan tol dan tokoh masyarakat.

Sedangkan data sekunder adalah data primer yang telah diolah atau diproses yang dapat disajikan dalam bentuk diagram atau tabel. Menurut Subagyo, (2015: 88) menjelaskan "Data sekunder adalah data yang diperoleh dari atau berasal dari bahan kepustakaan". Data sekunder berarti data yang berasal dari data primer yang diolah dalam bentuk diagram atau tabel. Selain dari bahan kepustakaan data sekunder dapat diperoleh dari dokumen yang dimiliki instansi yang bersangkutan, misalnya Peraturan desa, Profil Desa, foto hasil pembangunan maupun dokumen-dokumen yang ada dalam kantor desa.

Menurut Sugiyono (2007: 222) dalam penelitian kualitatif, yang menjadi instrumen atau alat penelitian adalah peneliti itu sendiri. Oleh karena itu peneliti sebagai instrumen juga harus "divalidasi" seberapa jauh peneliti kualitatif siap melakukan penelitian yang selanjutnya terjun ke lapangan, dengan demikian dalam penelitian kualitatif yang menjadi instrumen penelitian adalah peneliti itu sendiri karena pada penelitian kualitatif belum dapat dikembangkan instrumen penelitian sebelum peneliti mengetahui gambaran secara jelas ketika terjun di lapangan.

Adapun teknik pengumpulan data yang dipergunakan penulis dalam penelitian ini adalah sebagai berikut:

\section{Teknik Observasi}

Syaodih (dalam Satori dan Komariah, 2012: 105) menyatakan "Observasi (observation) atau pengamatan merupakan suatu teknik atau cara mengumpulkan data dengan jalan mengadakan pengamatan terhadap kegiatan yang sedang berlangsung".

\section{Wawancara}

"Wawancara atau interview adalah suatu bentuk komunikasi verbal jadi semacam percakapan yang bertujuan memperoleh informasi. Dalam wawancara pertanyaan dan jawaban diberikan secara verbal. Biasanya komunikasi ini dilakukan dalam keadaan saling berhadapan, namun komunikasi dapat juga dilaksanakan melalui telepon" (Nasution, 2012: 113).

\section{Dokumentasi}

Guba dan Lincoln (dalam Moleong, 2012: 216-217) menjelaskan "dokumen ialah setiap bahan tertulis ataupun film, lain dari record, yang tidak dipersiapkan karena adanya permintaan seorang penyidik". Metode ini sangat penting juga dalam mengumpulkan data karena jika ada kekeliruan datanya masih tetap karena yang di amati adalah benda mati. Pengumpulan data dengan meneliti catatan-catatan sangat penting dan sangat erat hubungannya dengan obyek penelitian.

Untuk mendapatkan data yang valid dan kredibel dalam penelitian diperlukan teknik keabsahan data. Dalam penelitian ini peneliti menggunakan teknik trianggulasi. Menurut Sugiyono, (2013: 241) "dalam teknik pengumpulan data, triangulasi diartikan sebagai teknik pengumpulan data yang bersifat menggabungkan dari berbagai teknik pengumpulan data dan sumber data yang telah ada".

\section{Teknik Analisis Data}

Setelah proses pengambilan data di lapangan langkah selanjutnya yaitu menganalisa data. Data yang diperoleh di lapangan di analisa untuk kemudian diperoleh kesimpulan yang sesuai dengan variabel dan masalah yang sedang diteliti.

Setelah data dari lapangan seperti wawancara, observasi, dan dokumentasi telah terkumpul, kemudian peneliti harus menganalisis data-data tersebut. Peneliti dalam menganalisis data harus dengan menggunakan indikator-indikator 
diskriptifnya sehingga perubahan-perubahan dapat terlihat. Analisis data dapat dilakukan sebelum di lapangan dan selama proses di lapangan.

Adapun analisis data selama dilapangan menurut model Milles dan Huberman (Satori dan Komariah, 2012: 218-220) ada 3 yaitu sebagai berikut:

\section{Reduksi Data (Reduction)}

Ketika peneliti mulai melakukan penelitian tentu saja akan mendapatkan data yang banyak dan relative beragam dan bahkan sangat rumit. Itu sebabnya, perlu dilakukan analisis data melalui reduksi data.Data yang diperoleh ditulis dalam bentuk laporan atau data yang terperinci. Laporan yang disusun berdasarkan data yang diperoleh direduksi, dirangkum, dipilih hal-hal yang pokok, difokuskan pada hal-hal yang penting. Data hasil mengikhtiarkan dan memilah-milah berdasarkan satuan konsep, tema, dan kategori tertentu akan memberikan gambaran yang lebih tajam tentang hasil pengamatan juga mempermudah peneliti untuk mencari kembali data sebagai tambahan atas data sebelumnya yang diperoleh jika diperoleh.

\section{Penyajian Data (data display)}

Selanjutnya sesudah mereduksi data adalah menyajikan data (data display).Teknik penyajian data dalam penelitian kualitatif dapat dilakukan dalam berbagai bentuk seperti tabel, grafik dan sejenisnya.Lebih dari itu, penyajian data bisa dilakukan dalam bentuk uraian singkat, bagan, hubungan antar kategori, flowchart dan sejenisnya. Adapun fungsi display data disamping untuk memudahkan dan memahami apa yang terjadi, juga untuk merencanakan kerja selanjutnya berdasarkan apa yang telah dipahami tersebut.

\section{Conclusion Drawing/Verification}

Langkah ketiga dalam analisis data kualitatif menurut Milles and Huberman adalah penarikan kesimpulan dan verifikasi. Kesimpulan awal yang dikemukakan masih bersifat sementara, dan akan berubah bila tidak ditemukan bukti-bukti yang kuat yang mendukung pada tahap pengumpulan data berikutnya. Tatapi apabila kesimpulan yang dikemukakan pada tahap awal, didukung oleh bukti-bukti yang valid dan konsisten saat peneliti kembali ke lapangan mengumpulkan data, maka kesimpulan yang dikemukakan merupakan kesimpulan yang kredibel.

\section{HASIL DAN PEMBAHASAN}

Pembangunan jalan tol ruas SoloKertosono yang melewati Desa Kasreman merupakan pembangunan yang diprogramkan oleh pemerintah pusat sebagai pembangunan infrastruktur jalan untuk mengurangi kemacetan di jalan raya SoloKertosono. Berdasarkan Peraturan Pemerintah Nomor 15 Tahun 2005 Tentang Jalan Tol, pembangunan jalan tol bertujuan untuk meningkatkan efisiensi pelayanan jasa distribusi guna menunjang peningkatan pertumbuhan ekonomi terutama di wilayah yang sudah tinggi tingkat perkembangannya. Infrastruktur jalan yang memadai dan lancar diharapkan pemerataan pembangunan dibidang ekonomi dapat terealisasi.

Dampak Pembangunan Jalan Tol SoloKertosono Terhadap Hak Ekonomi Masyarakat Desa Kasreman Kecamatan Geneng Kabupaten Ngawi.

Menurut Jimly Asshiddiqie (2016: 258-259) mengenai hak-hak yang termasuk kategori hak ekonomi dan sosial mencakup hak untuk bekerja, hak untuk mendapatkan upah yang sama dan hak atas makanan. Dampak pembangunan jalan tol SoloKertosono terhadap hak ekonomi masyarakat Desa Kasreman adalah sebagai berikut:

\section{Hak untuk Bekerja}

Hak untuk bekerja adalah hak yang dimiliki oleh seluruh manusia untuk mendapatkan pekerjaan sesuai dengan kemampuan atau keahlian yang dimiliki. Pembangunan jalan tol Solo-Kertosono yang melewati Desa Kasreman Kecamatan Geneng Kabupaten Ngawi seharusnya 
dalam proses pembangunan tersebut melibatkan masyarakat sekitar yang tanahnya terkena pembebasan lahan, hal tersebut dapat dilakukan sebagai upaya untuk mengganti sumber pendapatan lain dari para petani yang lahannya berkurang. Akan tetapi pembangunan jalan tol SoloKertosono tersebut tidak melibatkan masyarakat sekitar terutama masyarakat Desa Kasreman. Tenaga kerja yang dikerjakan pada pembangunan jalan tol adalah tanggung jawab PT Waskita, peran pemerintah desa dalam pembangunan jalan tol tersebut hanya sebagai penyalur aspirasi saat musyawarah sosialisasi tentang pembangunan jalan tol dan tidak diberi wewenang untuk merekrut tenaga pekerja.

Hak masyarakat Desa Kasreman terkait hak untuk bekerja pada saat pembangunan jalan tol tidak terjamin, baik sebagai petani yang lahannya terkena pembebasan lahan maupun selain petani yang tidak dapat ikut bekerja dalam proyek tersebut. Padahal masyarakat di Desa Kasreman sekitar 52,18\% masih menganggur. Jadi pembangunan jalan tol Solo-Kertosono tidak dapat berperan mengurangi pengangguran di Desa Kasreman karena pembangunan tersebut justru telah mengurangi lahan pertanian dan tidak menyerap tenaga pekerja dari masyarakat sekitar.

\section{Hak untuk mendapatkan upah yang sama}

Berdasarkan Undang-Undang Republik Indonesia Nomor 39 Tahun 1999 Tentang Hak Asasi Manusia, baik itu pria maupun wanita dalam melakukan pekerjaan yang sepadan dengan martabat kemanusiaannya berhak atas upah yang adil sesuai dengan prestasinya dan dapat menjamin kelangsungan kehidupan keluarganya. Pembangunan jalan tol yang tidak melibatkan masyarakat dalam pembangunan tersebut menyebabkan masyarakat yang terkena pembebasan lahan semakin mengalami kerugian. Masyarakat tersebut menganggap adanya perbedaan dan pemilihan dalam merekrut tenaga kerja untuk proyek jalan tol Solo-Kertosono tersebut.

\section{Hak atas makanan}

Setiap individu berhak untuk mendapatkan makanan, terbebas dari rasa kelaparan. Untuk itu setiap orang berhak untuk mendapatkan pekerjaan dan upah untuk bertahan hidup. Terjaminnya hak ekonomi masyarakat tergantung bagaimana mata pencaharian masyarakat tersebut diupayakan, sebab hak ekonomi berkaitan dengan aktifitas perekonomian yang bertujuan untuk mempertahankan hidupnya. Pembangunan jalan tol Solo-Kertosono menyebabkan hak atas makanan menjadi tidak tercukupi sebab pembangunan jalan tol Solo-Kertosono tersebut dibangun di atas lahan sawah produktif petani yang seharusnya setiap tahun masih menghasilkan produksi bahan pangan.

Hak ekonomi adalah hak asasi manusia bidang ekonomi yang berkaitan dengan aktifitas perekonomian, perburuhan, hak memperoleh pekerjaan, perolehan upah dan hak ikut serta dalam serikat buruh. Di Desa Kasreman aktifitas perekonomian lebih banyak bergerak pada sektor pertanian karena sebagian besar penduduk Desa Kasreman bermata pencaharian sebagai petani atau buruh. Pembangunan jalan tol Solo-Kertosono yang melewati lahan penduduk Desa Kasreman Kecamatan Geneng Kabupaten Ngawi memberikan pengaruh dan dampak pada hak ekonomi masyarakat Desa Kasreman terutama pada saat pembangunan jalan tol berlangsung. Pembangunan jalan tol yang melewati Desa Kasreman di atas lahan pertanian seluas sekitar 12 Ha mengakibatkan dampak pembangunan tersebut paling dirasakan oleh para petani dan pelaku usaha di Desa Kasreman.

Penduduk masyarakat Desa Kasreman Kecamatan Geneng sebagian besar bermata pencaharian sebagai petani dan buruh sebanyak 720 orang atau sebanyak $55,38 \%$ dari jumlah penduduk 
yang bekerja. Menurut data tersebut pendapatan penduduk Desa Kasreman sebagian besar bersumber pada kegiatan bertani hal itu terbukti dengan luas lahan persawahan di Desa Kasreman seluas 306,46 Ha. Perlindungan hak ekonomi masyarakat Desa Kasreman Kecamatan Geneng bergantung pada bagaimana mata pencaharian tersebut diupayakan agar senantiasa tetap berjalan dan tidak merugikan masyarakat sehingga hak ekonomi dapat terpenuhi.

\section{Pembangunan Jalan Tol yang Berwawasan Lingkungan}

Pembangunan jalan tol yang melewati lahan pertanian masyarakat Desa Kasreman merupakan pembangunan yang tidak berwawasan lingkungan karena pembangunan tersebut mengakibatkan lahan pertanian masyarakat yang produktif dengan 3 (tiga) kali panen menjadi hilang. Selain itu jalan desa menjadi rusak bahkan menyebabkan kecelakaan, hilangnya saluran irigasi dan jalan akses ke sawah seberang, serta meningkatnya polusi udara sebab jalan desa dilalui oleh kendaraan besar bermuatan material. Hasil penelitian tersebut sesuai dengan teori yang dijelaskan oleh Wisnu Arya yang mengemukakan bahwa pembangunan yang berwawasan lingkungan tidak dapat terlepas dari Analisis Mengenai Dampak Lingkungan (AMDAL).

Menurut Wisnu Arya (2001: 161-162) menjelaskan bahwa Analisis Mengenai Dampak Lingkungan (AMDAL) adalah suatu studi tentang beberapa masalah yang berkaitan dengan rencana kegiatan yang diusulkan. Dalam hal ini studi yang dilakukan meliputi kemungkinan terjadinya berbagai macam perubahan, baik perubahan sosial-ekonomi maupun perubahan biofisik lingkungan sebagai akibat adanya kegiatan yang diusulkan tersebut.

Dalam Analisis Mengenai Dampak Lingkungan (AMDAL) tersebut dijelaskan bahwa pembangunan yang mengakibatkan perubahan sosial-ekonomi maupun perubahan biofisik lingkungan sebagai akibat adanya kegiatan yang diusulkan tersebut merupakan pembangunan yang tidak berwawasan lingkungan. Pembangunan jalan tol yang berwawasan lingkungan seharusnya pembangunan yang tetap menjaga ekosistem lingkungan sekitar, tidak merusak ataupun menghancurkan ekosistem sekitar pembangunan.

\section{Mekanisme Ganti Rugi yang Sesuai Prosedur}

Berdasarkan

Undang-Undang

Republik Indonesia Nomor 2 Tahun 2012 Pasal 36-40 Tentang Pengadaan Tanah Bagi Pembangunan Untuk Kepentingan Umum, pemberian ganti rugi dapat diberikan dalam bentuk: uang, tanah pengganti, permukiman kembali, kepemilikan saham atau bentuk lain yang disetujui oleh kedua belah pihak. Mekanisme pemberian ganti rugi dilaksanakan dalam 2 (dua) tahap yaitu Musyawarah penetapan ganti kerugian dan Pemberian ganti kerugian.

Pembangunan jalan tol SoloKertosono di Desa Kasreman dibangun di atas lahan pertanian penduduk seluas sekitar 12 Ha. Lahan tersebut terdiri dari 183 sawah milik warga Kasreman dan 1 (satu) tanah kas desa. Masyarakat yang lahannya dibebaskan untuk pembangunan jalan tol diberi ganti rugi berupa uang tunai sesuai dengan luas tanah yang dibebaskan. Bapak SKC menyampaikan bahwa "Sistem ganti rugi dilakukan melalui musyawarah terlebih dahulu antara pemilik lahan, pihak pelaksana pembangunan jalan tol dan pemerintah desa. musyawarah dilakukan untuk mencapai kesepakatan harga tanah yang dibebaskan tersebut". Pendapat yang hampir sama juga disampaikan oleh Bapak SHT yang mengatakan,

"Ganti ruginya sudah sesuai dengan prosedur yaitu adanya pertemuan antara masyarakat, pihak pelaksana jalan tol dan pemerintah desa untuk memusyawarahkan mulai dari kesepakatan persetujuan jalan tol melewati lahan Desa Kasreman sampai dengan tawar menawar 
harga, pada mulanya harga yang ditawarkan tidak sesuai dengan keinginan warga tapi pada akhirnya warga setuju dengan harga jalan tengahnya yaitu harga tanah dibeli seharga Rp.70.000,- per meternya

Jadi sistem ganti rugi pembebasan lahan di Desa Kasreman untuk pembangunan jalan tol telah sesuai dengan prosedur yaitu Undang-Undang Nomor 2 Tahun 2012 Tentang Pengadaan Tanah Bagi Pembangunan Untuk Kepentingan Umum. Selain itu, tidak adanya masalah pada saat proses ganti rugi sampai dengan pemberian uang tidak ada kendala. Ganti rugi juga dilaksanakan dengan cara musyawarah mempertemukan pihak-pihak yang berkepentingan seperti masyarakat Desa Kasreman, pihak pelaksana dan pemerintah desa untuk mencapai kesepakatan harga tanah sebagai ganti rugi.

\section{Partisipasi atau Pelibatan Masyarakat Desa Kasreman dalam Pembangunan Jalan Tol}

Tahapan pembangunan jalan tol SoloKertosono terdiri dari 3 (tiga) tahap yaitu tahap perencanaan, tahap pelaksanaan dan tahap pengoperasian. Dari ketiga tahap tersebut masyarakat Desa Kasreman hanya ikut berpartisipasi pada pembangunan jalan tol dalam tahap perencanaan. Berdasarkan penelitian partisipasi masyarakat Desa Kasreman tersebut berupa ketersediaan masyarakat membebaskan lahannya untuk pembangunan jalan tol Solo-Kertosono. Pada tahap pelaksanaan masyarakat Desa Kasreman tidak ikut serta dalam proses pembangunan. Padahal berdasarkan teori partisipasi pembangunan bahwa pelibatan atau partisipasi masyarakat dalam suatu pembangunan seharusnya dari tahap perencanaan sampai dengan tahap pengendalian atau pengoperasian sehingga baik masyarakat maupun pemerintah saling mendapatkan manfaat dari pembangunan tersebut.

Menurut Aprillia Theresia, dkk (2014: 198) menjelaskan bahwa partisipasi masyarakat dalam pembangunan pada dasarnya adalah suatu bentuk keterlibatan dan keikutsertaan secara aktif dan sukarela, baik karena alasanalasan dari dalam (intrinsik) maupun dari luar (ekstrinsik) dalam keseluruhan proses kegiatan yang bersangkutan yang mencakup: pengambilan keputusan dalam perencanaan, pelaksanaan, pengendalian (pemantapan, evaluasi, pengawasan), serta pemanfaatan hasilhasil kegiatan yang dicapai.

Akan tetapi pada kenyataannya partisipasi masyarakat Desa Kasreman tidak semua ikut bekerja dalam pengerjaan proyek jalan tol tersebut karena keseluruhan tenaga kerja menjadi tanggung jawab PT Waskita atau pihak pelaksana pembangunan jalan tol Solo-Kertosono. Dari pihak PT Waskita sendiri tidak ada permintaan bantuan tenaga pekerja sehingga mayarakat tidak berani untuk mengajukan diri bek erja di proyek tersebut, jikapun ada warga yang bekerja diproyek tersebut hanya 2-3 orang yang bekerja pada bagian penjaga ruas pintu antar desa satu dengan desa lainnya pada malam hari. Seharusnya pembangunan jalan tol yang melewati Desa Kasreman tersebut dapat menjadi sumber pendapatan masyarakat sekitar khususnya bagi petani untuk mengganti sumber pendapatannya yang menurun karena lahan pertanian yang berkurang sehingga hak masyarakat dalam bidang ekonomi dapat terpenuhi dalam pembangunan jalan tol tersebut.

Di samping itu, berdasarkan hasil penelitian ditemukan fakta bahwa masyarakat Desa Kasreman yang terkena pembebasan lahan untuk pembangunan jalan tol Solo-Kertosono merupakan masyarakat yang mempunyai jiwa nasionalisme tinggi, hal itu dikarenakan bahwa masyarakat tersebut lebih mengutamakan kepentingan umum daripada kepentingan pribadi dengan kesediaan masyarakat lahannya dibebaskan untuk pembangunan jalan tol Solo-Kertosono. Masyarakat tesebut 
menyadari bahwa dengan mendukung program pemerintah dalam pembangunan jalan tol Solo-Kertosono maka masyarakat Desa Kasreman telah membantu program pemerintah dalam bidang lainnya, misalnya pembangunan dalam bidang ekonomi, sosial, penghematan bahan bakar minyak nasional.

\section{SIMPULAN DAN SARAN}

\section{Simpulan}

Berdasarkan hasil penelitian tentang dampak pembangunan jalan tol SoloKertosono terhadap hak ekonomi masyarakat Desa Kasreman Kecamatan Geneng Kabupaten Ngawi, maka dapat disimpulkan sebagai berikut:

Berdasarkan teori Wisnu Arya bahwa pembangunan akan membawa dampak bagi kehidupan manusia yaitu dampak positif yang meningkatkan kualitas dan kenyamanan hidup dan dampak negatif yang menurunkan kualitas dan kenyamanan hidup manusia. Dampak pembangunan jalan tol Solo-Kertosono terhadap hak ekonomi masyarakat Desa Kasreman membawa dua hal yaitu dampak positif dan negatif. Dampak positif yaitu menambah penghasilan bagi para pelaku usaha seperti warung makan, bengkel dan pemilik kendaraan truk pada saat pembangunan jalan tol tersebut berlangsung, meningkatkan perekonomian daerah yang tertinggal melalui terselenggaranya akses transportasi yang lancar dan cepat. Sedangkan dampak negatifnya yaitu bagi petani pembangunan jalan tol menyebabkan hasil panen menurun karena lahan yang digunakan untuk bertani semakin berkurang, jalan desa menjadi rusak.

Pembangunan jalan tol SoloKertosono melewati Desa Kasreman tidak dikategorikan sebagai pembangunan yang berwawasan lingkungan. Hal tersebut sesuai dengan teori Samhits Setiawan yang menjelaskan bahwa pembangunan yang berwawasan lingkungan harus sesuai dengan
Analisis Mengenai Dampak Lingkungan (AMDAL). Berdasarkan Analisis Mengenai Dampak Lingkungan (AMDAL) pembangunan yang ideal adalah apabila tidak terjadi dampak pencemaran lingkungan. Kalaupun terjadi suatu dampak, dampak tersebut hendaknya bersifat positif. Pembangunan jalan tol Solo-Kertosono dibangun di atas tanah persawahan produktif yang setiap tahun terdiri dari 3 (tiga) kali panen. Meningkatnya polusi udara karena dilewati oleh kendaraan besar bermuatan material, saluran irigasi sawah hilang dan tidak ada akses jalan menuju sawah seberang. Pembangunan yang berwawasan lingkungan tidak merusak tanah atau lingkungan yang masih berproduksi tinggi untuk memenuhi kehidupan masyarakat setempat. Seharusnya pembangunan jalan tol tidak melewati lahan pertanian yang masih produktif.

Mekanisme ganti rugi atas pembebasan lahan untuk pembangunan jalan tol telah sesuai prosedur yaitu UndangUndang Nomor 2 Tahun 2012 Tentang Pengadaan Tanah Bagi Pembangunan Untuk Kepentingan Umum dan tidak ada masalah. Pemberian ganti rugi berdasarkan UndangUndang tersebut dapat diberikan dalam bentuk: uang, tanah pengganti, permukiman kembali, kepemilikan saham atau bentuk lain yang disetujui oleh kedua belah pihak. Mekanisme pemberian ganti rugi dilaksanakan dalam 2 (dua) tahap yaitu Musyawarah penetapan ganti kerugian dan Pemberian ganti kerugian. Mekanisme ganti rugi pembangunan jalan tol Solo-Kertosono yang melewati Desa Kasreman dilakukan secara musyawarah untuk mendapatkan kesepakatan harga antara pemilik lahan dan pihak pelaksana dan lahan yang dibebaskan untuk jalan tol dibeli dengan harga dua kali lipat dari harga pada umumnya.

Pembangunan jalan tol SoloKertosono tidak melibatkan masyarakat pada saat tahap pelaksanaannya dan hanya melibatkan masyarakat pada saat tahap perencanaan melalui sosialisasi mengenai 
pembangunan jalan tol Solo-Kertosono yang melewati Desa Kasreman. Sebanyak 2-3 orang saja yang bekerja dipembangunan tersebut dan hanya sebagai penjaga ruas tol antar satu desa dengan desa lainnya pada waktu malam hari. Pembangunan jalan tol menjadi tanggung jawab PT Waskita termasuk para tenaga kerjanya. Dari pemerintah desa sendiri tidak diberi kesempatan untuk mengikutsertakan warganya bergabung dalam pekerjaan pembangunan sehingga tidak ada warga yang ikut terlibat dalam pekerjaan proyek tersebut. Padahal jika masyarakat Desa Kasreman ikut dalam pekerjaan proyek tersebut maka akan menambah pendapatan masyarakat setempat.

\section{Saran}

Berdasarakan hasil pembahasan maka penulis memberikan saran kepada pemerintah desa, masyarakat desa dan pengambil kebijakan mengenai hak ekonomi masyarakat dengan adanya pembangunan jalan tol Solo-Kertosono yaitu sebagai berikut:

\section{Untuk Pemerintah Desa}

Pemerintah Desa Kasreman harus dapat menampung aspirasi atau keluhan dari masyarakat terkait pembangunan jalan tol Solo-Kertosono yang melewati Desa Kasreman untuk kemudian disampaikan kepada penanggung jawab pembangunan jalan tol. Peranan kepala desa dan pemerintah desa dalam melindungi dan menegakkan hak ekonomi masyarakat Desa Kasreman sangatlah penting karena hak ekonomi masyarakat menjadi kewajiban pemerintah untuk menjaminnya. Pemerintah Desa Kasreman harus mampu melihat keadaan ekonomi masyarakat Desa Kasreman secara menyeluruh dan berusaha mengupayakan untuk menjamin hak ekonomi tersebut. Kesejahteraan masyarakat Desa Kasreman salah satunya bergantung pada terjaminnya hak ekonomi masyarakat untuk bekerja dan mendapatkan upah.

Untuk Masyarakat
Masyarakat harus ikut berpartisipasi dalam pembangunan jalan tol yang melewati Desa Kasreman karena pembangunan tersebut seharusnya dapat memberikan peluang usaha dan peluang kerja untuk meningkatkan pendapatan masyarakat sekitar pembangunan. Pembangunan jalan tol merupakan salah satu pembangunan yang bertujuan untuk memberikan kesejahteraan masyarakat secara menyeluruh. Tidak hanya masyarakat tertentu yang dapat menikmati hasil pembangunan akan tetapi juga masyarakat yang berada dalam area pembangunan berlangsung harus mendapatkan manfaat dari program pembangunan tersebut.

\section{Untuk Pengambil Kebijakan}

Pembangunan jalan tol seharusnya dapat dilaksanakan sebagai bentuk pembangunan yang berwawasan lingkungan. Pembangunan jalan tol merupakan kebijakan yang diambil oleh pemerintah pusat sebagai bentuk pembangunan infrastruktur negara yang membutuhkan lahan sangat luas. Diperlukan perhatian dari pihak pengambil kebijakan terhadap masyarakat mengenai pekerjaan, pendapatan yang hilang akibat pembangunan jalan tol misalnya melalui program pendampingan atau pelatihan bagi petani dan bukan petani mengenai cara berwirausaha sehingga masyarakat Desa Kasreman tetap mendapatkan hak ekonominya sebagai warga negara Indonesia.

\section{DAFTAR PUSTAKA}

Adisasmito, R. (2013). Pembangunan Pedesaan - Pendekatan Partisipati Tipologi, Strategi, Konsep Desa Pusat Pertumbuhan. Yogyakarta: Graha Ilmu.

Asshiddiqie, J. (2016). Konstitusi Ekonomi. Jakarta: Kompas

Badan Pengantar Jalan tol Kementerian PU dan Perumahan Rakyat. (2005). Kebijakan dan Strategi Pembangunan 
Citizenship Jurnal Pancasila dan Kewarganegaraan Vol 3 No 1 Maret 2017, hal 108-120

Avaliable online at : http://e-journal.unipma.ac.id/index.php/Citizenship

ISSN: 2302-433X (print) 2579-5740 (online)

Jalan Tol. Seminar Tantangan dan Strategi Truk Angkutan Barang Dalam Menciptakan Keunggulan Bersaing. Banten: Asosiasi Pengusaha Truk Indonesia.

(http://supplychainindonesia.com/new/ download/529/., diunduh tanggal 4 Mei 2017)

Deklarasi Universal Hak-Hak Asasi Manusia

(https://www.komnasham.go.id, diunduh tanggal 20 April 2017)

Djam'an, S. dan Komariah, A. (2012). Metodologi Penelitian Kualitatif. Bandung: Alfabeta.

El-Muhtaj Majda.(2007). Hak Asasi Manusia Dalam Konstitusi Indonesia: Dari UUD 1945 sampai dengan Amandemen UUD 1945 Tahun 2002. Jakarta: Kencana.

Hartomo dan Aziz, A. (1999). Llmu Sosial Dasar. Jakarta: Bumi Aksara

Herdiwanto, H dan Hamdayama, J. (2010). Cerdas, Kritis, Dan Aktif Berwaganegara: Pendidikan Kewarganegaraan Untuk Perguruan Tinggi. Jakarta: Erlangga.

Hermawan R, Rodhiatun, Al Rasyid, $\mathrm{H}$. (2015). Kajian Investasi Pembangunan Jalan Tol di Indonesia Berdasarkan Sistem Syariah: Studi Kasus Jalan Tol Cikampek-Palimanan.

Jurnal Perencanaan Wilayah dan Kota, 26 (2), $86-$ 99.(http://digilib.mercubuana.ac.id/eartikel1.php?No_Artikel $=0000017440$ , diunduh tanggal 30 Mei 2017)

Iqbal Febri. (2015). Pemenuhan Hak Ekonomi Melalui Coporate Social Respon sibility Industry Kayu Lapis Di Desa Nguwet Kecamatan Kranggan Kabupaten Temanggung. Jurnal Penelitian Hukum, 2 (3), 125136.

(https://jurnal.ugm.ac.id/jph/article/vie $\underline{\mathrm{w} / 19120}$, diunduh tanggal 18 April 2017)
Konvenen Internasional Hak-Hak Ekonomi, Sosial dan Budaya. (http://humanrightspapua.org/resource s/intllaw/81-kihesb, diunduh tanggal 5 April 2017)

Mardikanto, T dan Soebiato, P. (2013). Pemberdayaan Masyarakat Dalam Perspektif Kebijakan Publik. Bandung: Alfabeta.

Moleong, Lexy J. (2012). Metodologi Penelitian Kualitatif. Bandung: Remaja Rosdakarya.

Munandar, S. (2011). Ilmu Sosial Dasar Teori dan Konsep Ilmu Sosial. Bandung: PT Refika Aditama

Nasution, S. (2012). Metode Research (Penelitian Ilmiah). Jakarta: Bumi Aksara.

Peraturan Pemerintah No 15 Tahun 2005 (http://hubdat.dephub.go.id, diunduh tanggal 5 April 2017)

Rosyada, D. (2005). Demokrasi Hak Asasi Manusia dan Masyarakat Madani. Jakarta: Prenada Media.

Setiadi, E.M., Hakam, K.A., dan Effendi, R. (2007). Ilmu Sosial dan Budaya Dasar. Jakarta: Kencana Prenada Media Group

Subagyo, J. (2015). Metode Penelitian dalam Teori dan Praktek. Jakarta: Rineka Cipta.

Subawa, I. (2008). Hak Asasi Manusia Bidang Ekonomi Sosial dan Budaya Menurut Perubahan UUD 1945. Kertha Patrika, 33 (1). 1-7. (https://ojs.unud.ac.id/index.php/kerth apatrika/article/view/3263/2342, diunduh tanggal 12 Mei 2017)

Suprayitno, B. (2012). Privatisasi Jalan Tol Sebagai Solusi Dalam Mempercepat Terwujudnya Infrastruktur Jalan Tol Yang Memadai Di Indonesia. Jurnal Economia, 8 (1), 65-77.

http://portalgaruda.org/article.php?arti $\underline{\text { cle }=52409 \& \mathrm{val}=473}$, diunduh tanggal 4 Mei 2017)

Sugiyono. (2013). Cara Mudah Menyusun Skripsi, Tesis, dan Disertasi (STD). Bandung: Alfabeta. 
Citizenship Jurnal Pancasila dan Kewarganegaraan Vol 3 No 1 Maret 2017, hal 1o8-120 Avaliable online at : http://e-journal.unipma.ac.id/index.php/Citizenship ISSN: 2302-433X (print) 2579-5740 (online)

(2007). Metode Penelitian Kuantitatif, Kualitatif, dan $R \& D$. Bandung: Alfabeta.

Theresia, A., Andini, K.S., Nugraha, P.G., dan Mardikanto, T. (2014). Pembangunan Berbasis Masyarakat: Acuan Bagi Praktisi, Akademisi, dan Pemerhati Pengembangan Masyarakat. Bandung: Alfabeta.

Undang-Undang Dasar Negara Republik Indonesia Tahun 1945. (2003). Surakarta: Nusantara.
Undang-Undang Republik Indonesia Nomor 6 Tahun 2014 Tentang Desa (www.hukumonline.com, diunduh tanggal 14 April 2017)

Wardhana, Wisnu Arya. (2001). Dampak Pencemaran Lingkungan. Yogyakarta: ANDI. 